\title{
The performance of 'Adara' as a cherry rootstock
}

\author{
M.A. Moreno ${ }^{a, *}$, L. Montañés ${ }^{b}$, M.C. Tabuenca ${ }^{a}$, and R. Cambra ${ }^{a}$ \\ ${ }^{a}$ Departamento de Pomología, ${ }^{b}$ Departamento de Nutrición Vegetal. Estación Experimental \\ de Aula Dei (Consejo Superior de Investigaciones Científicas), Apartado 202,
}

50080 Zaragoza, Spain

\section{Abstract}

The field performance of Adara (Prunus cerasifera L.), SL 64 (P. mahaleb) and Colt (P. avium X P. pseudocerasus) rootstocks grafted with two sweet cherry cultivars ( $P$. avium L. cvs. 'Van' and 'Tardif de Vignola'), were tested for 12 years on a calcareous clayloam soil which was flood irrigated. No tree grafted on Adara died during the experiment. The percentage of dead trees of 'Tardif de Vignola' on SL 64 and Colt reached 63\% and $19 \%$, respectively. In turn, the percentage of dead trees of 'Van' was $19 \%$ when grafted on SL 64 and 6\% on Colt. For 'Van' scion, Adara was the most invigorating rootstock and showed the greatest yield efficiency and cumulative production after 12 years. For 'Tardif de Vignola' scion, Adara also gave greater cumulative production, mean fruit weight, and vigour than SL 64 and Colt. Leaf mineral analysis of 'Van' trees showed a mineral element concentration closer to the optimum for the trees grafted on Adara than on SL 64 and Colt. According to our results, Adara seems to be a suitable rootstock for cherry cultivars to avoid root asphyxia in heavy soils and/or under flood irrigation conditions, where other

\footnotetext{
${ }^{*}$ Corresponding author.
} 
rootstocks fail to survive. Similarly, it also performs well in calcareous soils, which are not favourable for other cherry rootstocks.

Key words: Prunus spp.; vigour; yield; yield efficiency; fruit weight; mineral elements.

Abbreviations: TCSA, trunk cross-sectional area; C.I.I., Comité Inter-Institutos; DAFB, days after full bloom.

\section{Introduction}

In Spain and other Mediterranean countries, P. mahaleb (St. Lucie) and a clonal selection of it named SL 64, are widely used as cherry rootstocks in gravely, well-drained, droughty and calcareous soils. However, P. mahaleb rootstocks are unsuitable on heavy soils or where waterlogging occurs (Breton et al., 1972; Perry, 1987). Colt, a hybrid rootstock (P. avium X P. pseudocerasus) has been reported as semidwarfing, precocious, and easy to propagate (Webster, 1981). More recently Colt has been shown to be an invigorating rootstock in deep and fertile soils (Perry, 1987; Bononad et al., 1988) but poorly adapted to some other cherry growing areas of Spain (Bononad et al., 1988). Adara is a plum rootstock developed at the Estación Experimental de Aula Dei, Zaragoza (Spain), for use as an invigorating rootstock for different stone fruit species (Tabuenca and Moreno, 1988). Adara probably belongs to the myrobalan group (P. cerasifera) (Moreno, 1989), a fast growing plum according to Bernhard and Grasselly (1958). As for other selections of the myrobalan group, Adara has been shown tolerant to wet and compact soil conditions where root asphyxia is common. This rootstock is readily propagated by hardwood cuttings and has a wide range of compatibility with sweet cherry scion cultivars (Moreno and Tabuenca, 1991; Moreno et 
al., 1995). In this study, we report the performance of Adara, as compared with SL 64 and Colt, when tested as rootstocks with two sweet cherry cultivars in a calcareous and clayloam soil. Rootstock performance was assessed both from vigour and cropping characteristics, as well as from analysis of leaf mineral status.

\section{Materials and methods}

The trial was carried out at the Estación Experimental de Aula Dei on calcareous soil, with a high total (30\%) and active (11\%) lime, $\mathrm{pH}=8$, and clay-loam texture.

'Van' and 'Tardif de Vignola' sweet cherry cultivars were grafted on Adara, $P$. mahaleb SL 64 and Colt rootstocks. Trees were planted at a spacing of $5 \times 4 \mathrm{~m}$ in the winter of 1982-1983, and were allowed to develop naturally with little pruning throughout the experiment. The orchard was managed following the usual local procedures, including flood irrigation. In the orchard, four rows of trees, two of 'Van' and two of 'Tardif de Vignola', were established. Each cultivar was placed in alternate rows to allow similar conditions for pollination. The experiment was designed as randomised blocks with 16 single-tree replications for each scion/stock combination. The two inner rows, one of each cultivar, were used to evaluate growth and cropping performance (eight replications). The two guard rows were also used for tree survival record (16 replications).

For the cropping years, starting in 1987, trunk circumference, yield, and mean fruit weight per tree were recorded. Trunk circumference was measured during the dormant season at $20 \mathrm{~cm}$ above the graft union, and trunk cross-sectional area (TCSA) was calculated. Cumulative yield per tree and yield efficiency (cumulative kilogram per tree/TCSA) of each scion/stock combination were computed from the harvest data. 
Leaf mineral element concentrations were determined in the 12th year after planting for 'Van' trees with no asphyxia symptoms and/or associated diseases. Leaf samples were collected from five blocks, i.e. five single-tree replications of each Van graft combination. Sampling was carried out on two dates: 60 days after full bloom (DAFB), i.e. one week before harvest maturity, and at 110 DAFB. Leaf analyses were carried out according to the methods of C.I.I. (1969) and C.I.I. et al. (1975). Total N was determined by the Kjeldahl method; P by the phosphor-vanadate colorimetric method; $\mathrm{K}$ by atomic emission spectroscopy; and $\mathrm{Ca}, \mathrm{Mg}, \mathrm{Fe}, \mathrm{Mn}, \mathrm{Cu}$ and $\mathrm{Zn}$ by atomic absorption spectroscopy (Pye Unicam SP9).

The data were evaluated by analysis of variance using the SPSS program (Norusis, 1986). Values from dead trees were considered as missing data. Means were separated by Fisher's (protected) LSD $(P \leq 0.05)$ when the F test was significant.

\section{Results}

Mortality of trees. - While no trees of Adara died, the percentage of dead trees of 'Tardif de Vignola' on SL 64 and Colt reached 63\% and 19\%, respectively. The percentage of dead trees of 'Van' was 19\% when grafted on SL 64 and 6\% on Colt. Tree losses were distributed throughout the life of the trial. After the first visual symptoms of wilting, early defoliation and death of shoots and branches took place. The following year, the trees or most of its branches died.

Tree vigour and yield characteristics. - TCSA, mean fruit weight, yearly and cumulative yield, and yield efficiency were significantly influenced by rootstock. 
Yields for both cultivars were reduced by spring frosts in 1990. A strong and unusual hailstorm could have also affected fruit set in 1993. The number of flowers was usually less on the scions grafted on Colt than on those grafted on Adara or SL 64 (data not shown).

For 'Van' trees (Table 1, Fig. 1), yield for all the cropping years, and cumulative production by the 12th year after planting, were greater on Adara than on Colt and SL 64 rootstocks. Yields of 'Van' grafted on SL 64 were greater than those on Colt in all cropping years, as was also the case for cumulative production by the 12th year after planting. Colt induced earlier harvest maturity, 1-3 days in some years, probably due to its limited production compared with the other rootstocks. TCSA was significantly smaller on Colt than on Adara and SL 64 rootstocks. Adara was the most invigorating rootstock although differences were not significant when compared with SL 64. The yield efficiency of 'Van' grafted on Adara was significantly greater than on the other rootstocks. Differences in yield efficiency between SL 64 and Colt rootstocks were not detected due to the greater vigour of SL 64. Mean fruit weight of 'Van' over 5 years (1990 to 1994) was similar on Adara and SL 64 and greater than on Colt.

Yield and vigour comparisons for 'Tardif de Vignola' trees (Table 2) were discontinued after the 9th year of scion growth in the orchard, owing to their high mortality, especially when grafted on SL 64. Yields, for most of the cropping years, and cumulative production by the 9th year after planting, were greater on Adara rootstock. However, in general, low yields of 'Tardif de Vignola' were found for all rootstocks, because of the fewer flowers and poor fruit set of this cultivar. Harvest maturity date was similar on all rootstocks. TCSA was significantly greater on Adara compared to SL 64 and Colt. The yield efficiency of 'Tardif de Vignola' trees on Adara and SL 64 were similar, and 
significantly greater than on Colt. Mean fruit weight of 'Tardif de Vignola' over 3 years (1990 to 1992) was greater on Adara than on the other rootstocks.

Leaf colour and mineral element concentration. - Leaf yellowness was observed for 'Van' and 'Tardif de Vignola' when grafted on Colt and SL 64. These symptoms were more acute on Colt. No symptoms were observed when these scions were grafted on Adara.

To determine differences between rootstocks in the efficiency of nutrient uptake, concentration of macro- and micronutrients in leaves of 'Van' cultivar were obtained. The results showed that most nutrients were affected by the rootstock (Table 3). Leaf concentrations of $\mathrm{N}, \mathrm{K}$, and Mn were significantly higher with Adara than with SL 64 or Colt, both before and after fruit harvest. The lowest $\mathrm{N}$ and $\mathrm{K}$ concentrations were found on Colt rootstock on both dates. In contrast, leaf $\mathrm{Ca}$ and $\mathrm{Mg}$ concentrations were greater on Colt and SL 64 than on Adara. Leaf P concentration was highest on SL 64, intermediate on Adara and lowest on Colt. Rootstock had no effect on leaf Fe concentration. An effect of the rootstock on leaf $\mathrm{Cu}$ concentration was only found in the first sampling (60 DAFB). At this time, the $\mathrm{Cu}$ content was lowest for Colt trees. In contrast, the $\mathrm{Zn}$ concentration was highest on Colt, although differences between this rootstock and Adara only were statistically significant in the second sampling.

\section{Discussion}

In our experiments Adara showed a good adaptation to compact soils under flood irrigation conditions, since all trees on this rootstock showed a healthy appearance. In contrast, trees on Colt and especially on SL 64 had a high level of mortality. Substantial tree losses on P. mahaleb, SL 64, Colt and other rootstocks have been reported for cherries 
(Mircetich et al., 1976; Larsen et al., 1987; Bononad et al., 1988). In the case of Colt, tree mortality has been attributed to the sensitivity to root asphyxia (Bononad et al., 1988), though Claverie et al. (1985) got good results in heavy and wet soils using this rootstock. In the case of $P$. mahaleb and the clone SL 64, tree mortality has also been related with the sensitivity to root asphyxia and susceptibility to various root rot pathogens as Phytophthora or Stereum purpureum (Mircetich and Matheron, 1976; Bauman and Engel, 1986). In our work, the presence of these pathogens was not evaluated.

The rootstock Adara profoundly affected the fruiting response of 'Van' and 'Tardif de Vignola' sweet cherries compared to the other two rootstocks studied. The good adaptation of Adara to the growing conditions probably favoured higher yield, vigour, yield efficiency and fruit weight. The effect on yield and yield efficiency was more evident with 'Van' as scion, since the yields of 'Tardif de Vignola' appeared to be reduced by fewer flowers and poor fruit set, probably due to female sterility (A. Arbeloa, personal communication). Colt was the least invigorating rootstock, and also the least productive, confirming the findings of Perry (1987) and Bononad et al. (1988), who indicated that trees on Colt are greatly reduced in vigour when grown in heavy and calcareous soils. Adara showed the greatest vigour. In general, invigorating rootstocks are unsuitable, nevertheless a higher vigour may be advisable when planting on poor soils or under replanting conditions. The highest fruit weight induced by Adara is a desirable marketable trait since thinning is unusual in cherry.

Leaf mineral analysis showed that the nutrient status of Adara was close to the optimum, according to the reference values for cherry reported by Leece (1975). In contrast, SL 64 and Colt trees showed deficiency or close to deficiency values for $\mathrm{K}, \mathrm{N}$ and $\mathrm{Mn}$, and values higher than normal for $\mathrm{Ca}$ and $\mathrm{Mg}$. For all rootstocks, the levels of $\mathrm{Cu}$ and Fe were close to optimum (Leece, 1975). Zinc concentrations were slightly lower than 
normal. The low Zn concentrations in trees on the SL 64 rootstock are noteworthy, as $P$. mahaleb have been reported less prone to Zn deficiency than other rootstocks (Breton et al., 1972).

There are few clonal rootstocks for cherries which are adapted to heavy and calcareous soils and poor growing conditions. P. mahaleb SL 64 has been successfully used as a rootstock in arid and calcareous soils in Spain, but it performs poorly in heavy soils and under flood irrigation conditions. A similar response has been reported for other rootstocks as Grand Manil selections (R. Gella, personal communication) or Colt (Bononad et al., 1988). The use of Adara as a rootstock for cherries could help growers avoid root asphyxia in wet and heavy soils or under irrigation conditions, where other rootstocks fail to survive. Adara also performs well in calcareous soils, which are not favourable for other cherry rootstocks. However, it lacks compatibility with a few cherry cultivars (Tabuenca and Moreno, 1988; Moreno and Tabuenca, 1991), and further evaluation of its performance under a wide range of orchard soil conditions is needed.

\section{Acknowledgements}

Financial support was provided by Comisión Asesora de Investigación Científica y Técnica and Comisión Interministerial de Ciencia y Tecnología. M.A. Moreno was supported by Consejo Asesor de Investigación de la Diputación General de Aragón and Consejo Superior de Investigaciones Científicas. We thank Drs. A. Arbeloa, A. Casas and R. Austin for critical reading of the manuscript. We gratefully acknowledge Drs. A. Blanco and E. Igartua for helpful discussions, as well as A. Almudí, J. Aparicio and J. Pérez for the management of plant material in the orchard. 


\section{References}

Baumann, G. and Engel, G., 1986. Clonal selection in Prunus mahaleb rootstocks. Acta Hortic., 180: 91-94.

Bernhard, R. and Grasselly, C., 1958. Les pruniers porte-greffes du pêcher. Station de Recherches d'Arboriculture Fruitière. La Grande-Ferrade. Bordeaux, pp. 75-100.

Bononad, S., De Andrés, T., Diez, B., Espada, J.L., Reinoso, D., and Cambra, R., 1988. Comportamiento del patrón de cerezo 'Colt', en algunas localidades españolas. ITEA, 77: 43-51.

Breton, S., Jeandet, C., Mesnil, G., Trillot, M., Vidaud, J., Viard, M.P., and Fourel, M.A., 1972. Le Cerisier, Monographies de l'Invuflec. Institut National de Vulgarisation pour les fruits, legumes et champignons. Paris, France, 235 pp.

C.I.I., 1969. Comité Inter-Institutos para el estudio de técnicas analíticas. Métodos de referencia para la determinación de elementos minerales en vegetales. An. Edaf. Agrobiol., 38:403-417.

Comité Inter-Institutes (C.I.I.), Pinta, M. and DeWaele, G., 1975. Etalons végétaux pour l'analyse foliaire. In: P. Kozma (Editor), Le contrôle de l'alimentation des plantes cultivées. Akadémiai Kiadó. Budapest, pp. 159-172.

Claverie, J., Edin, M., Tronel, C., and Garcin, A., 1985. Un nouveau porte-greffe pour les bigarreaux: le Colt. Arboric. Fruit., 377: 43-49.

Larsen, F.E., Higgins, S.S. and Fritts, R.Jr., 1987. Scion/interstock/rootstock effect on sweet cherry yield, tree size and yield efficiency. Scientia Hortic., 33: 237-247.

Leece, D., 1975. Diagnostic leaf analysis for stone fruits. 5. Sweet Cherry. Austral. J. Exper. Agric. Anim. Husb., 15: 118-122. 
Mircetich, S.M., and Matheron, M.E., 1976. Phytophthora root and collar rot of cherry trees. Phytopathology, 66: 549-558.

Mircetich, S.M., Schreader, W.R., Moller, W.J., and Micke, W.C., 1976. Root and crown rot of cherry trees. California Agric., 30: 10-11.

Moreno, M.A., 1989. Características descriptivas del patrón ciruelo ‘Adara’. An. Aula Dei, 19: 293-300.

Moreno, M.A, and Tabuenca, M.C., 1991. El patrón ciruelo ‘Adara’: su comportamiento con variedades de cerezo y de otras especies frutales. ITEA, 87: 25-35.

Moreno, M.A., Tabuenca, M.C. and Cambra, R., 1995. Adara, a plum rootstock for cherries and other stone fruit species. HortScience, 30 (in press).

Norusis, M.J., 1986. Statistical Package for the Social Sciences/PC+, for the IBM PC/XT/AT. SPSS Inc., Chicago, Illinois, USA.

Perry, R.L., 1987. Cherry rootstocks. In: R.C. Rom and R.F. Carlson (Editors), Rootstocks for fruit crops. John Wiley \& Sons, New York, pp. 217-264.

Tabuenca, M.C., and Moreno, M.A., 1988. Incompatibilidad entre patrón e injerto. Comportamiento de un ciruelo como patrón de distintas especies frutales. An. Aula Dei, 19: 251-263.

Webster, A.D., 1981. Dwarfing rootstocks for plums and cherries. Acta Hortic., 114: 201207. 
Table 1. Rootstock effects on trunk cross-sectional area (TCSA) and yield characteristics of 'Van' sweet cherry after 12 years in the orchard.

\begin{tabular}{lcccc} 
& & Cumulative & Yield & Mean \\
& TCSA & yield & efficiency & fruit wt \\
Rootstock & $\left(\mathrm{cm}^{2}\right)$ & $(\mathrm{kg} / \mathrm{tree})$ & $\left({\left.\mathrm{kg} . \mathrm{cm}^{-2}\right)}\right.$ & $(\mathrm{g})$ \\
\hline Adara & $427 \mathrm{~b}^{\mathrm{z}}$ & $321 \mathrm{c}$ & $0.77 \mathrm{~b}$ & $6.9 \mathrm{~b}$ \\
SL 64 & $332 \mathrm{~b}$ & $200 \mathrm{~b}$ & $0.61 \mathrm{a}$ & $7.0 \mathrm{~b}$ \\
Colt & $170 \mathrm{a}$ & $105 \mathrm{a}$ & $0.63 \mathrm{a}$ & $6.0 \mathrm{a}$
\end{tabular}

${ }^{\bar{z}}$ Mean separation within columns by Fisher's (protected) LSD at $P \leq 0.05$.

Table 2. Rootstock effects on trunk cross-sectional area (TCSA) and yield characteristics of ‘Tardif de Vignola’ sweet cherry after 9 years in the orchard. 


\begin{tabular}{lcccc} 
& & Cumulative & Yield & Mean \\
& TCSA & yield & efficiency & fruit wt \\
Rootstock & $\left(\mathrm{cm}^{2}\right)$ & $(\mathrm{kg} / \mathrm{tree})$ & $\left(\mathrm{kg} \cdot \mathrm{cm}^{-2}\right)$ & $(\mathrm{g})$ \\
\hline Adara & $345 \mathrm{~b}^{\mathrm{z}}$ & $136 \mathrm{c}$ & $0.39 \mathrm{~b}$ & $7.5 \mathrm{~b}$ \\
SL 64 & $207 \mathrm{a}$ & $76 \mathrm{~b}$ & $0.34 \mathrm{~b}$ & $6.9 \mathrm{a}$ \\
Colt & $151 \mathrm{a}$ & $31 \mathrm{a}$ & $0.20 \mathrm{a}$ & $7.0 \mathrm{a}$
\end{tabular}

${ }^{\mathrm{z}}$ Mean separation within columns by Fisher's (protected) LSD at $P \leq 0.05$. 
Table 3. Rootstock effects on leaf mineral element concentrations of 'Van' sweet cherry at 60 days (60 D) and 110 days (110 D) after full bloom, by the 12th year of scion growth in the orchard. Results for N, P, K, Ca and Mg are expressed as percentage of dry matter and for Fe, Mn, Cu and Zn, as mg.kg-1.

\begin{tabular}{|c|c|c|c|c|c|c|c|c|c|c|}
\hline \multirow[b]{2}{*}{ Rootstock } & \multicolumn{2}{|c|}{$\mathrm{N}$} & \multicolumn{2}{|c|}{$\mathrm{P}$} & \multicolumn{2}{|c|}{$\mathrm{K}$} & \multicolumn{2}{|c|}{$\mathrm{Ca}$} & \multicolumn{2}{|c|}{$\mathrm{Mg}$} \\
\hline & $60 \mathrm{D}$ & $110 \mathrm{D}$ & $60 \mathrm{D}$ & $110 \mathrm{D}$ & $60 \mathrm{D}$ & $110 \mathrm{D}$ & $60 \mathrm{D}$ & $110 \mathrm{D}$ & $60 \mathrm{D}$ & $110 \mathrm{D}$ \\
\hline Adara & $2.95 c^{z}$ & $2.09 \mathrm{c}$ & $0.36 \mathrm{~b}$ & $0.41 \mathrm{ab}$ & $1.92 \mathrm{c}$ & $1.23 \mathrm{c}$ & $1.62 \mathrm{a}$ & $1.87 \mathrm{a}$ & 0.48 a & $0.46 \mathrm{a}$ \\
\hline SL 64 & $2.65 \mathrm{~b}$ & $1.96 \mathrm{~b}$ & 0.41 c & $0.44 \mathrm{~b}$ & $1.39 \mathrm{~b}$ & $0.78 \mathrm{~b}$ & $2.53 \mathrm{~b}$ & $2.71 \mathrm{~b}$ & $0.74 \mathrm{~b}$ & $0.70 \mathrm{~b}$ \\
\hline Colt & $2.31 \mathrm{a}$ & $1.72 \mathrm{a}$ & $0.31 \mathrm{a}$ & $0.34 \mathrm{a}$ & $0.92 \mathrm{a}$ & $0.42 \mathrm{a}$ & $2.92 \mathrm{~b}$ & $3.46 \mathrm{c}$ & $0.87 \mathrm{c}$ & $0.89 \mathrm{c}$ \\
\hline
\end{tabular}

\begin{tabular}{|c|c|c|c|c|c|c|c|c|}
\hline \multirow[b]{2}{*}{ Rootstock } & \multicolumn{2}{|c|}{$\mathrm{Fe}$} & \multicolumn{2}{|c|}{$\mathrm{Mn}$} & \multicolumn{2}{|c|}{$\mathrm{Cu}$} & \multicolumn{2}{|c|}{$\mathrm{Zn}$} \\
\hline & $60 \mathrm{D}$ & $110 \mathrm{D}$ & $60 \mathrm{D}$ & $110 \mathrm{D}$ & $60 \mathrm{D}$ & $110 \mathrm{D}$ & $60 \mathrm{D}$ & $110 \mathrm{D}$ \\
\hline Adara & $131.5 \mathrm{a}$ & $159.1 \mathrm{a}$ & $64.1 \mathrm{~b}$ & $64.3 \mathrm{~b}$ & $12.2 \mathrm{~b}$ & $10.2 \mathrm{a}$ & $20.0 \mathrm{ab}$ & $15.1 \mathrm{a}$ \\
\hline SL 64 & $147.2 \mathrm{a}$ & $155.2 \mathrm{a}$ & $47.6 \mathrm{a}$ & $47.3 \mathrm{a}$ & $11.4 \mathrm{~b}$ & $10.3 \mathrm{a}$ & $16.6 \mathrm{a}$ & $12.6 \mathrm{a}$ \\
\hline Colt & $150.2 \mathrm{a}$ & $161.6 \mathrm{a}$ & $41.8 \mathrm{a}$ & $47.6 \mathrm{a}$ & $9.0 \mathrm{a}$ & $9.4 \mathrm{a}$ & $23.6 \mathrm{~b}$ & $20.5 \mathrm{~b}$ \\
\hline
\end{tabular}

\footnotetext{
${ }^{\mathrm{z}}$ Mean separation within columns by Fisher's (protected) LSD at $P \leq 0.05$.
} 
Figure legend

Figure 1. Yield of 'Van' grafted on Adara, SL 64 and Colt rootstocks, from the fifth (1987) to the 12th (1994) year after planting.

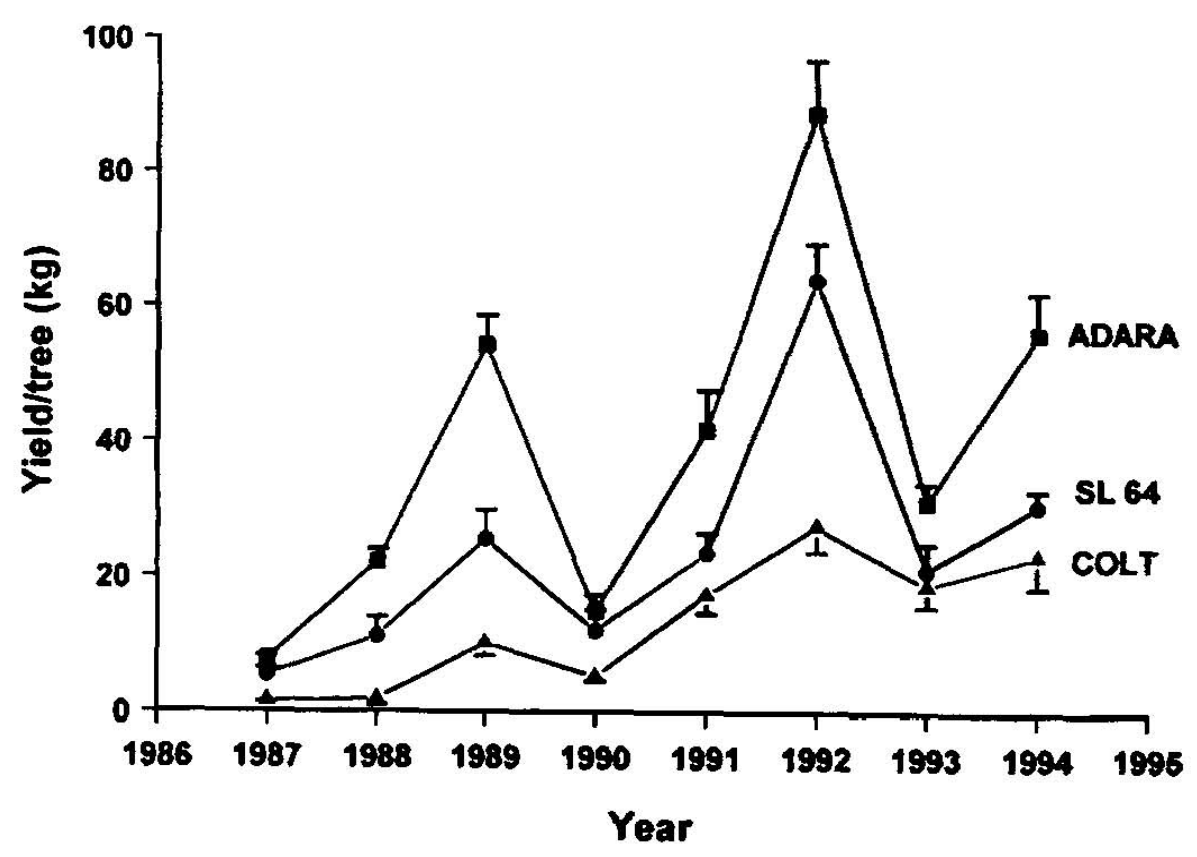

